\title{
Neisseria gonorrhoeae
}

National Cancer Institute

\section{Source}

National Cancer Institute. Neisseria gonorrhoeae. NCI Thesaurus. Code C86603.

A species of aerobic, Gram-negative, diplococci shaped bacteria assigned to the phylum Proteobacteria. This species is oxidase and catalase positive, grows best on blood agar medium or chocolate medium, is non-hemolytic, produces acid from glucose, but not from maltose, fructose, sucrose, mannose or lactose, does not synthesize polysaccharides, and reduces nitrite but not nitrate. N. gonorrhoeae is the causative agent of gonorrhea and is transmitted via sexual contact. 